\title{
Advantages of the Public Water Supply Use for Micro Power Generation
}

\author{
Sérgio Ramos ${ }^{1}$ (scr@isep.ipp.pt); António Gomes ${ }^{1}$ (aag@isep.ipp.pt); Marílio Cardoso² (joc@isep.ipp.pt);Luís \\ Castanheira1 ${ }^{1}$ (1cc@isep.ipp.pt) ${ }^{1}$; \\ ${ }^{1}$ Department of Electrical Engineering, Polytechnic Institute of Oporto, Portugal \\ GECAD - Knowledge Engineering and Decision Support Group \\ \{scr, aag, lcc\}@isep.ipp.pt \\ ${ }^{2}$ Department of Computer Engineering, Polytechnic Institute of Oporto, Portugal \\ GECAD - Knowledge Engineering and Decision Support Group \\ joc@isep.ipp.pt
}

Instituto Superior de Engenharia do Porto

Rua Dr. António Bernardino de Almeida, 431 4200-072 Porto

Phone: 00351228340500 (Ext. 1114) Fax: 228321159

\begin{abstract}
The public water system consists of several stations water, pumping plants, primary interconnection networks, tanks and secondary distribution networks to final customers.

There are expressive differences of elevation value between the various components of the storage and distribution of water system. Thus, there are high levels of available kinetic energy in these installations.

This work focuses the use of this energy for electricity energy generation, through the integration of micro hydric in public water distribution networks.
\end{abstract}

\section{Key words}

Renewable energy, hydric energy, endogenous resources, micro generation.

\section{Interest of this work}

The electricity production using renewable energy sources has seen a boom in recent years. This expansion has been, in large part, based on two factors: the rising prices of fossil fuels and the development of a greater environmental awareness.

The hydropower plants are classified, as to their power, such as: hydropower plants, (PInst. > $10 \mathrm{MW}$ ); small hydroelectric (2 MW <PInst. <10 MW); minihydroelectric $(0,5 \mathrm{MW}<$ PInst. < $2 \mathrm{MW})$; microhydroelectric (PInst. <0,5 MW). Furthermore the minihydropower plants can also be classified according to their height of water fall, including: high downfall (exceeding 150 meters), medium fall (between 20 to 150 meters), and low fall, where the water fall height can vary between 2 and 20 meters.

The European Union (EU), with the Directive 2001/77/EC, recognizes the need to promote renewable energy sources considering being strategic vectors in environmental protection and sustainable development.

In Portugal, the EU directive has resulted in a strategic plan for the promotion of renewable energy program called E4 (Energy Efficiency and Energy Endogenous). With this support program, Portugal aims to achieve the target of $39 \%$ of electric power from renewable energy established in the directive 2001/77/EC.

In Portugal, the total renewable installed capacity reached 7.868,00 MW in late July 2008.

Table I presents the historical evolution of the total installed power in renewable energy sources (MW in continental Portugal).

Table II presents the current situation of electricity production from renewable energies in Portugal.

In order to meet the targets proposed by the Kyoto Protocol it is necessary to continue investing in the expansion of productive capacity in renewable energy.

The micro-hydropower production proposed in this paper aims to contribute to this objective and to the exploitation of a potential, which until now has been neglected. 
Table I - Historical evolution of the total installed power in renewable (MW) in continental Portugal

\begin{tabular}{|c|c|c|c|c|c|c|c|c|c|}
\hline & 2001 & 2002 & 2003 & 2004 & 2005 & 2006 & 2007 & $\begin{array}{c}\text { Julho } \\
2008\end{array}$ & TCMA \\
\hline Hídrica Total & 4263 & 4288 & 4292 & 4561 & 4752 & 4802 & 4805 & 4809 & $2,0 \%$ \\
\hline Grande Hídrica (>30MW) & 3783 & 3783 & 3783 & 4043 & 4234 & 4234 & 4234 & 4234 & $1,9 \%$ \\
\hline $\mathrm{PCH}(>10$ e $<=30 \mathrm{MW})$ & 240 & 251 & 251 & 251 & 232 & 281 & 281 & 281 & $2,7 \%$ \\
\hline $\mathrm{PCH}(<=10 \mathrm{MW})$ & 240 & 254 & 258 & 267 & 286 & 287 & 290 & 294 & $3,2 \%$ \\
\hline Eólica & 114 & 175 & 253 & 537 & 1047 & 1681 & 2108 & 2556 & $62,6 \%$ \\
\hline Biomassa (c/ cogeração) & 344 & 372 & 352 & 357 & 357 & 357 & 357 & 357 & $0,6 \%$ \\
\hline Biomassa (s/ cogeração) & 8 & 8 & 8 & 12 & 12 & 24 & 24 & 24 & $20,1 \%$ \\
\hline Resíduos Sólidos Urbanos & 88 & 88 & 88 & 88 & 88 & 88 & 88 & 88 & $0,0 \%$ \\
\hline Biogás & 1,0 & 1,0 & 1,0 & 7,0 & 8,2 & 8,2 & 12,4 & 12,4 & $52,1 \%$ \\
\hline Fotovoltaica & 1,3 & 1,5 & 2,1 & 2,7 & 2,9 & 3,4 & 14,5 & 21,4 & $49,5 \%$ \\
\hline \multicolumn{10}{|l|}{ Ondas/Marés } \\
\hline Total & 4819 & 4934 & 4996 & 5565 & 6267 & 6964 & 7409 & 7868 & $7,4 \%$ \\
\hline
\end{tabular}

TCMA - Taxa de Crescimento Média Anual entre 2001 e 2007

Table II - Current situation of electricity production from renewable energy sources in Portugal

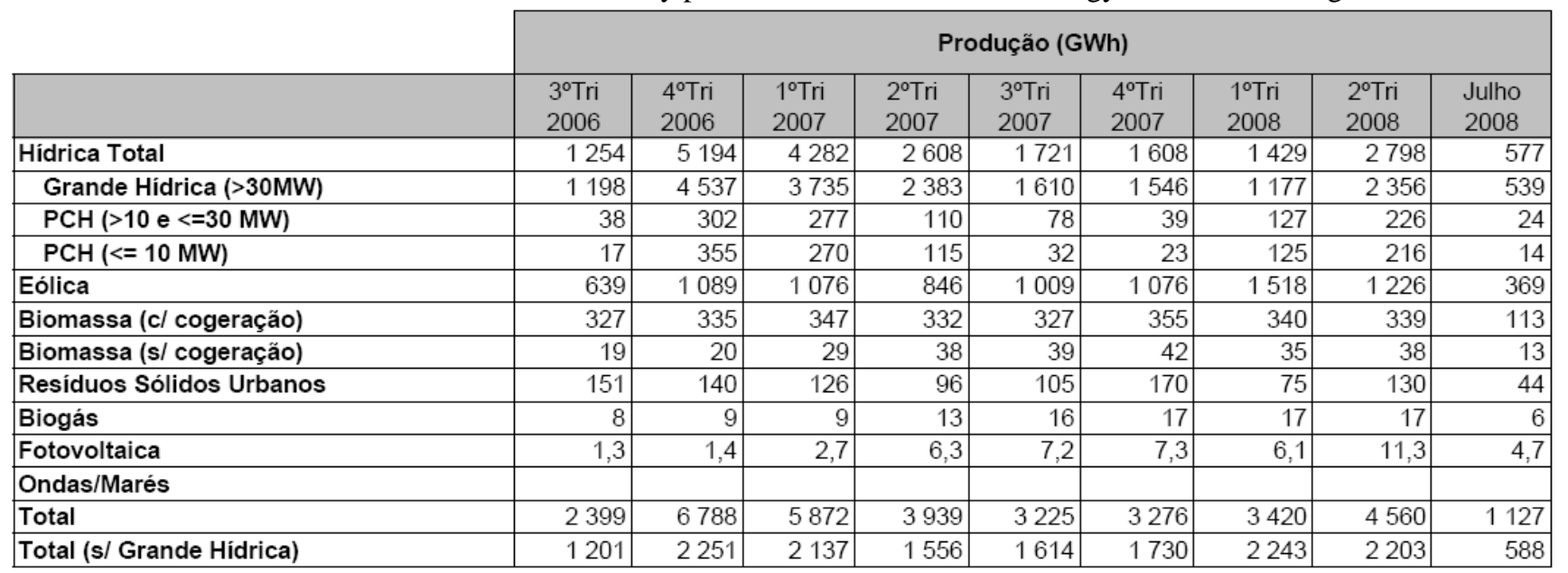

\section{Nominal Flow}

For the definition of nominal flow it was used length of flow curves. In a first approach the turbine is sized for a flow that is exceeded between $15 \%$ and $40 \%$ of the days of the year. The choice of this percentage depends on the shape of the curve length of flow, and in large part, on the expert's experience [1].

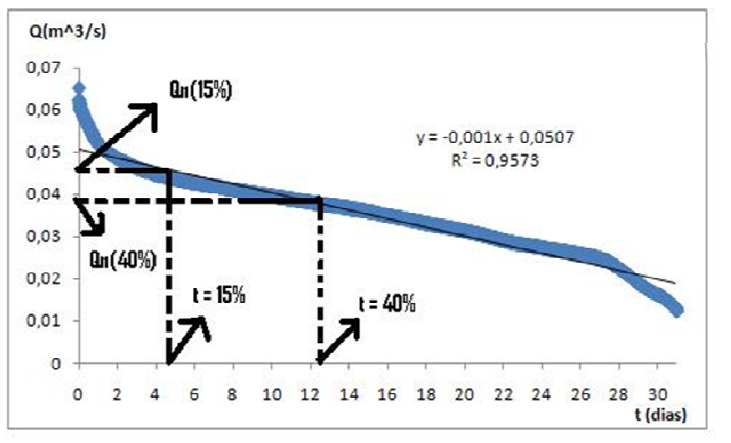

Figure 1 - Selection of the nominal flow through a length of flow curve

As mentioned in [1], and in general, the hydrological study which is based on a hydroelectric exploitation should be carried out by experts in hydrology. Thus, the electric engineer must take into account the basic logic that guides the flow estimation. The flow passing through a section of a river is a random variable, with non-uniform distribution throughout the year. Thus, the hydrological studies can only provide probabilities of occurrence of tributaries flow to a particular section of the watercourse (usually daily average values) over the year.

The hydrological analysis to support the feasibility studies of hydroelectric plants has as its main goal to get a curve called average duration curve of average daily flow, or more simply, duration curve flow.

This curve is an average curve supported by observations made over several years and its significance is decisive. In the case of the rivers is generally accepted that a period of thirty to forty years is the ideal to take as significant the average curve obtained. As the case study presented is based on the use of a water network distribution, the historical flow can be drastically reduced since its flow is not subject to natural variation in comparison of the rivers flow. Thus, a few years of historical data may be sufficient to obtain the representative water flow curve, obtaining the nominal average flow of the studied distribution system. 


\section{Turbine Choice}

To make the choice of the turbine it is basically necessary to know the details of the height of water fall and the nominal flow. In establishing these two parameters it will be obtained the power available and it can be possible to choose the right turbine that fits best. To make this choice there is a kind of abacus to support, in a simple way, the selection of the type and power of the turbine.

The choice of the turbine type should be extremely careful because it represents a significant portion of the total cost of the installation (around 50\%) [1].

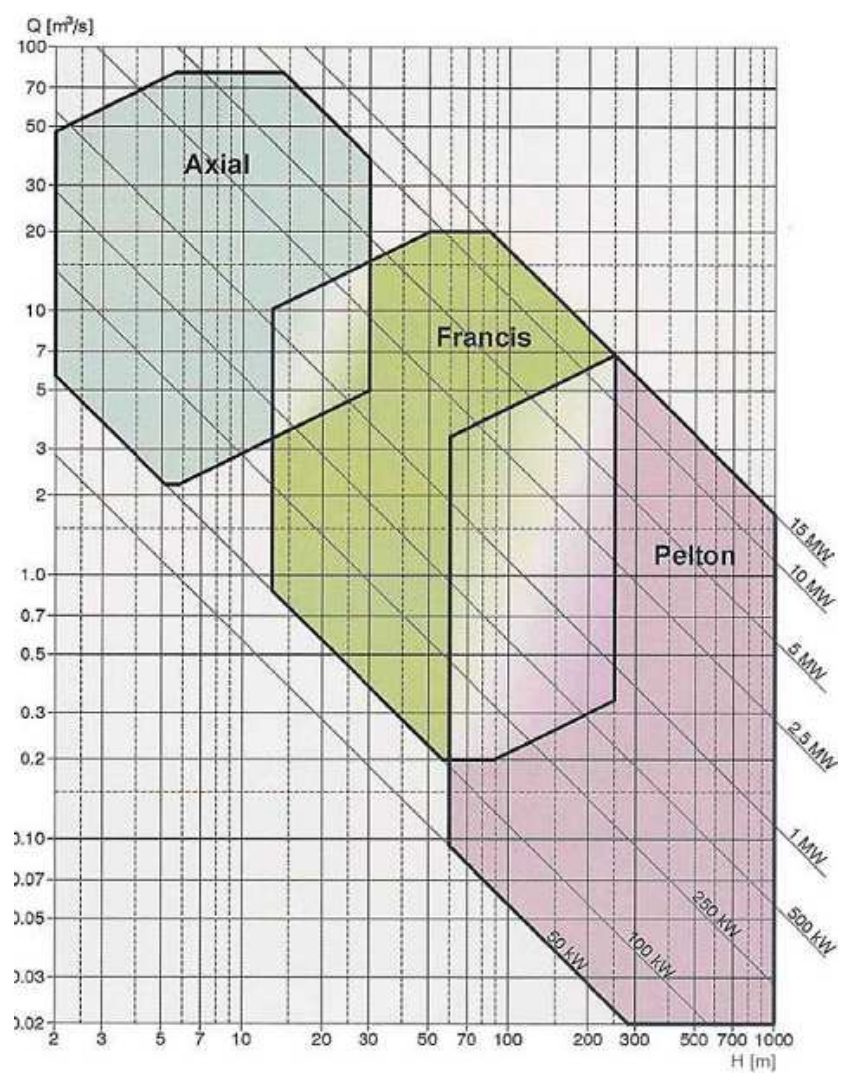

Figure 2 - Graphical selection of turbines for minihydropower plants [2]

The choice of the turbine type results essentially from the interaction of three parameters:

- Water fall;

- Water flow

- Power.

Figure 2 provides a graphic table used in the selection of turbines for small hydroelectric plants.

The turbines (of action) are more appropriate for a utilization characterized by relatively high falls and reduced flows value. In mini-hydropower plants it is usually used Pelton turbines (action) operating with intermediate water falls (20 to 100 meters) and with powers ranging between 50 and $500 \mathrm{~kW}$. In intermediate water falls it usually used Francis turbine, but can also be used Banki-Mitchell turbines. The low water downfalls are the domain of axial turbines - Kaplan, and the BankMitchell turbine may also be used in this range falls.
Figures 4 and 5 show the various types of these mentioned turbines [1]

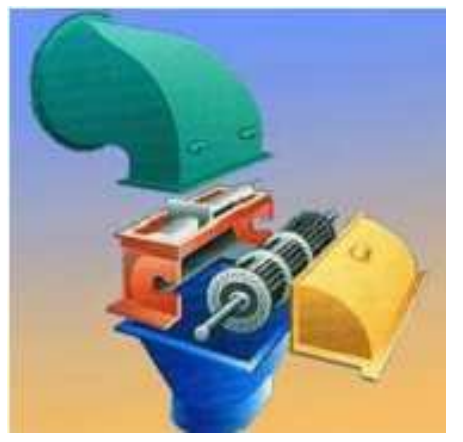

Figure 3 - Banki-Mitchell Turbine

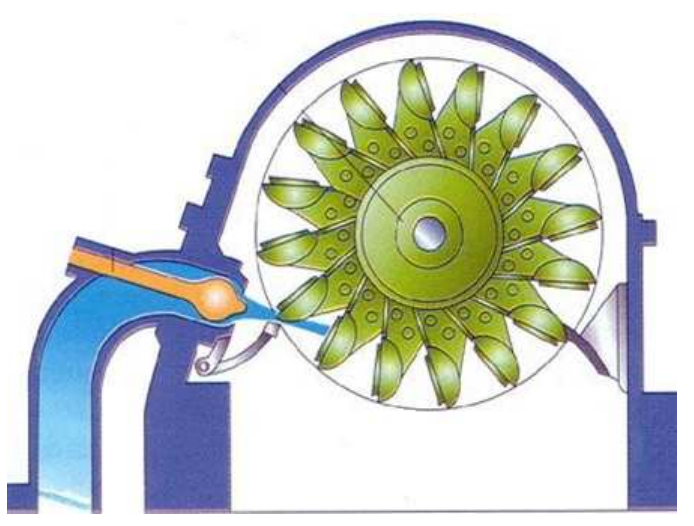

Figure 4 - Pelton Turbine

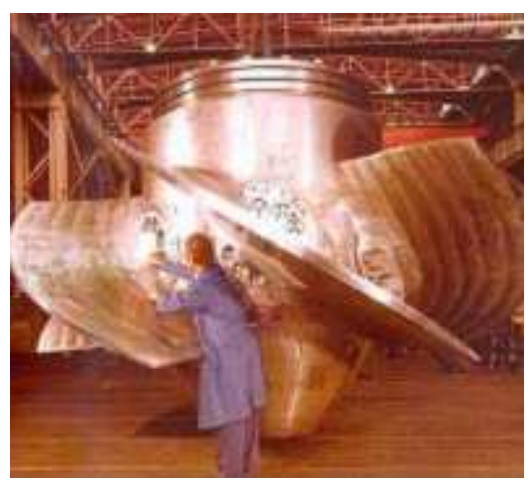

Figure 5 - Kaplan Turbine

In very small power generation - micro-power plants - it has been proposed the use of pumps running in reverse way, as turbines. Despite a reduction of the operation performance and inability to adapt to the water flow, this solution presents interesting advantages such as low price, market availability, easy assembly and reduced maintenance.

\section{Generator Choice}

The choice of the generator to equip a minihydropower plant depends on the specifications imposed on the turbine, with respect to efficiency, nominal speed, constant of inertia, type of regulation, etc. 
A fundamental choice is focused in between the synchronous generator (alternator) and asynchronous generator.

The asynchronous generator is, in general, technical and economically preferable, because of its known characteristics of robustness, reliability and economy. In higher power plants are required more elaborate technical solutions and the economic aspects are less critical, so the synchronous generator is usually the chosen converter.

In Portugal, it is verified that the most of small hydro power plants are equipped with synchronous generators.

\section{Case study}

This paper presents a study of a pilot project for exploiting the kinetic energy of the difference between the height value of the water deposits of "Ramalde" and "Pedrouços" belonging to the distribution network and water supply services, for the production of electricity, through the integration of a micro-water use in the interconnection conduct between the two tanks.

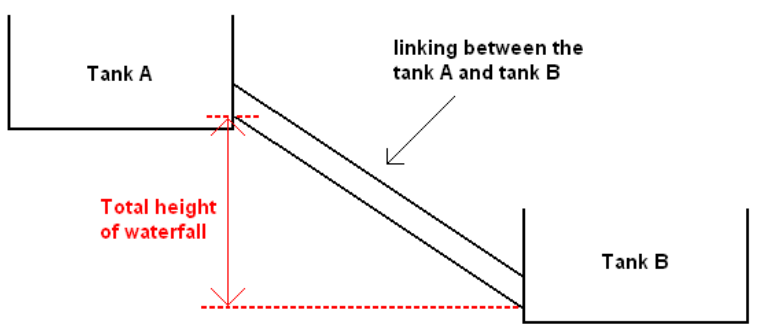

Figure 6 - Model supply system type

The option for the use of network interconnection between these two deposits, Ramalde and Pedrouços, due to the fact that for existing a kinetic energy of water it is necessary to have a water flow so that allows that energy can be generated in a continuous way, otherwise there could represents a significant change in the generated power.

Tables III and IV show the collected data, relating to the water reservoirs characteristics, of each of the two tanks, "Ramalde" and "Pedrouços".

Table III - Data from Ramalde reservoir

\begin{tabular}{|r|r|}
\hline Situation & Working \\
\hline Floor area $\mathbf{( m 2 )}$ & 1626,81 \\
\hline Height base $\mathbf{( m )}$ & 182,58 \\
\hline Full height of storage $\mathbf{( m )}$ & 188,73 \\
\hline Shape & Rectangular \\
\hline Volume of water $\mathbf{( m 3 )}$ & 10000 \\
\hline
\end{tabular}

Table IV - Data from Pedrouços reservoir

\begin{tabular}{|r|r|}
\hline Situation & Working \\
\hline Floor area $\mathbf{( m 2 )}$ & 800 \\
\hline Height base $\mathbf{( m}$ & 159,9 \\
\hline
\end{tabular}

\begin{tabular}{|r|r|}
\hline Full height of storage (m) & 166,15 \\
\hline Shape & Circle \\
\hline Volume of water $(\mathbf{m} 3)$ & 5000 \\
\hline
\end{tabular}

In this case study, the quota difference between the two reservoirs is approximately 22.6 meters. This is the value that is considered as useful downfall water.

The following figure features the network's daily average water flow that has been described and that was conveniently monitored and recorded.

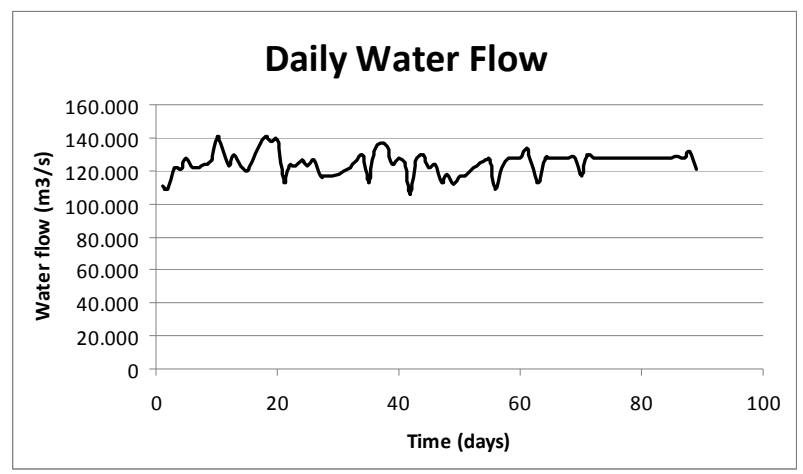

Figure 7 - Daily water flow of the Ramalde-Pedrouços reservoirs.

The analysis is done through flow curves and the data were recorded with a cadence of 10 minutes. Thus, there is a large number of historical data to deal in order to define and characterize the daily and monthly curve flow profile.

After the analysis and preparation of flow curves it was calculated the value of the power to install.

In installation connected to the electricity grid, the initial hypothesis should be the installation of a single group turbine/generator. Using the curve length of flow the turbine is first sized for a nominal flow turbinate equal to that which is exceeded by about $15 \%$ ( 55 days) to $40 \%$ (146 days) days in the average year [3], [4].

The maximum hydraulic power that can be obtained through a difference in height can be calculated by the following equation:

$$
P=\eta \cdot \rho \cdot g \cdot Q \cdot H
$$

Where, in units of the International System of Units (SI):

Power (P): W

Efficiency $(\eta)$ : percentage

Density $(\rho): \mathrm{kg} / \mathrm{m} 3$

Acceleration of gravity $(\mathrm{g}): \mathrm{m} / \mathrm{s} 2$

Fall $(\mathrm{H}): \mathrm{m}$

Volumetric water flow (Q): m3 / s

In such exploitations the typical efficiency is around $80 \%$, which is the value that was considered to the power estimation. In this case, the fluid is the water, so its density is $1000 \mathrm{~kg} / \mathrm{m} 3$, and their specific weight it will be: 
$\eta . \rho=1000 * 9,81=9810 \mathrm{~N} / \mathrm{m}^{3}$

To determine the flow value same measurements of the daily flow for about three months were made, having been obtained the average value of $126,450 \mathrm{~m}^{3} /$ day which corresponds to an average volumetric flow of 1,46 $\mathrm{m}^{3} / \mathrm{s}$. Thus, the estimated power to be installed it will be:

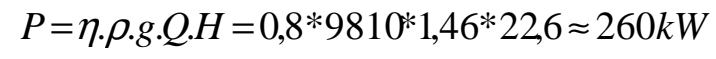

And the estimated annual energy:

$E=P .8760 \approx 260 * 8760=2277600 k W h \approx 2,28 \mathrm{GWh}$

Assuming an average value of $0,05 € / \mathrm{kWh}$, the amount corresponding to the energy produced would be:

$$
2277600 * 0,05=113.880,00 € / \text { year }
$$

According to the Portuguese law, the Order No. $17313 / 2008$ of 26 June 2008, published under the point a) of paragraph 2 of Article 19 of the DL No. 71/2008 of 15 April, the conversion of kWh of electric energy to "tep" is given by the following expression:

$$
\text { ElectricEnergy }=\frac{\eta}{86 * 10^{-6}}(\text { tep } / \mathrm{kWh})
$$

Thus, for an efficiency of $80 \%$ and considering that the generated power is consumed locally, it would have:

ElectricEnergy $=\frac{0,8}{86 * 10^{-6}}=9302 \mathrm{tep} / \mathrm{kWh}$

Where:

$$
1 k W h=107,5 * 10^{-6} \text { tep }
$$

Therefore, the electrical energy produced annually would be:

$$
2277600 * 107,5 * 10^{-6}=244,8 \text { tep }
$$

The project of a mini-hydropower plant is an iterative process that involves the balance of revenue and costs for several possible solutions for nominal power. The initial hypothesis will be the installation of a single group turbine / generator.

The turbine is chosen for a nominal flow rate, that there will be only around $20 \%$ to $30 \%$ of days, on a normal year.

The turbine efficiency depends on the turbine flow, so the turbines operating limits are imposed, so it is established a permissible operation range around the nominal flow without appreciable efficiency variation. Outside this range, the turbine is off, for lack of efficiency.
Table $\mathrm{V}$ indicates the factors of the exploration limits on the basis of the turbinate flow [3], [5].

Table V - Limit for the turbines operation

\begin{tabular}{|l|c|c|}
\hline \multicolumn{1}{|c|}{ Turbina } & $\alpha_{1}=\frac{Q_{\text {min }}}{Q_{N}}$ & $\alpha_{2}=\frac{Q_{\text {Max }}}{Q_{N}}$ \\
\hline Pelton & 0,15 & 1,15 \\
\hline Francis & 0,35 & 1,15 \\
\hline Kaplan com dupla regulação & 0,25 & 1,25 \\
\hline Kaplan com rotor regulado & 0,4 & 1,0 \\
\hline Hélice & 0,75 & 1,0 \\
\hline
\end{tabular}

As long as the downfall of the system between the two water reservoirs is relatively low and considering the value of the water flow, the turbine most appropriate for this case is the Kaplan turbine.

\section{Conclusions and Further Work}

This paper presents a micro-hydropower plant to be used in the public network of water distribution, which is in the process of public consultation for the electrical project and the later award of execution.

The potential of this type of projects is very significant and allows decentralized power generation and that generation is nearest of the centres of major consumption, with the consequent reduction of losses inherent in the transport and distribution of electricity. It also allows to promote the use of a resource that is usually unexploited, contributing to achieve the goals of energy production from renewable sources and promoting environmental protection and sustainable development.

As future work the authors expect to execute a study comparing the use of different types of turbines and the presentation of the financial study concerning the different studied cases.

\section{References}

[1] Castro, Rui M. G., "Introdução à energia MiniHídrica", Março de 2008.

[2] Penche, Celso, "Guide on How to Develop a Small Hydropower Plant", Thematic Network on Small Hydropower (TNSHP), European Small Hydropower Association - ESHA, 2004.

[3] Moura, Domingos, "Aproveitamentos hidroeléctricos de pequena potência" (preliminary drafting), manuscript text, IST, 1987. 
[4] P. Vilas Boas, Graça Medina, Manuela Portela, “A metodologia de projecto de uma pequena central hidroeléctrica", Seminário Avançado Tecnologias das Fontes de Energia Eléctrica Descentralizadas, IST, Maio 1986.

[5] Betâmio, A. de Almeida, "Planeamento de pequenas centrais hidroeléctricas", Seminário Avançado Tecnologias das Fontes de Energia Eléctrica Descentralizadas, IST, Maio 1986.

[6] European Commission, Directive 2001/77/EC for the promotion of electricity from renewable energy sources in the internal electricity market, 27 September, 2001.

[7] Conselho de Ministros, Resolução do Conselho de Ministros no 154/2001, 27 September 2001.

[8] Conselho de Ministros, Resolução do Conselho de Ministros no 63/2003, 28 April, 2003.

[9] Comissão Europeia, Comunicação da Comissão ao Conselho e ao Parlamento Europeu: A quota das energias renováveis na EU, 26 de Maio de 2005.

[10] Direcção Geral de Energia e Geologia, renováveis, estatísticas rápidas, Julho 2008.

[11] Ferreira, P., Trindade, M., Martins, J. S., Afonso, J. L. Interfaces for Renewable Energy Sources with Electric Power Systems, Environment 2010: Situation and Prespectives for the European Union, Porto, Portugal, Maio de 2003.

[12] S. R. Bull, Renewable Energy Today and Tomorrow, Proceedings of the IEEE, Vol. 89, No. 8, August, 2001, pp. 1216-1226.

[13] Ramos, Helena \& Betânio, Almeida, "O Benefício Económico e Ambiental da Produção de Energia Renovável em Sistemas Adutores", Instituto Superior Técnico de Lisboa.

[14] Ramos, Helena \& Betânio, Almeida, "Small Hydropower schermes as an Important Renewable Energy Source", Instituto Superior Técnico de Lisboa.

[15] Harvey, Adam \& Brown, Andy et all, "Micro-hydro design Manual - A Guide to Small-scale Water Power Schemes", 2006.

[16] Fernandes, José Miguel, "Estudo da Viabilidade Técnico-económica do potencial de produção de energia hidroeléctrica no sistema de abastecimento das Águas do Cávado, S.A." Instituto Superior de Engenharia do Porto, Novembro 2008. 